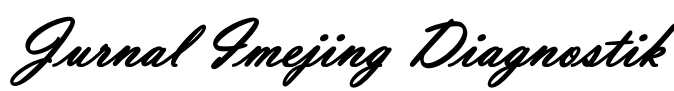

e-ISSN 2621-7457, p-ISSN 2356-301X

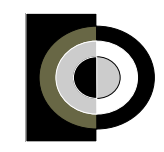

http://ejournal.poltekkes$\underline{\text { smg.ac.id/ojs/index.php/jimed/index }}$

\title{
Informasi Citra Anatomi pada Penggunaan Variasi Increment Pemeriksaan MSCT Abdomen Irisan Axial Kasus Nodul Hepar
}

\author{
Selfia Claudiana Rahma Dewi ${ }^{1}$, dr. Arinawati ${ }^{2}$, Darmini $^{3}$, Dimas Prakoso ${ }^{4}$ \\ ${ }^{1)}$ Blora Hospital, Indonesia \\ ${ }^{2)}$ Doctor of Community Health Center of Semarang, Indonesia \\ 3. 4) Poltekkes Kemenkes Semarang, Indonesia \\ Correspondng Author: Selfia Claudiana Rahma Dewi \\ e-mail: selfiacrd@gmail.com
}

Received: January $29^{\text {th }}, 2021$; Revised: January $30^{\text {st }}, 2021$; Accepted: February $31^{\text {st }}, 2021$

\begin{abstract}
Background: Liver nodules are tumors that are less than $2 \mathrm{~cm}$ in size and are single or multiple. In making a diagnosis of liver nodules can be done by examination of abdominal MSCT. According to Seeram (2009), using 50\% overlapping there was an increase in nodule detection by $10 \%$ compared to incremental increments. The purpose of the study was to determine differences in information on anatomical images on the use of increment variations in abdominal MSCT examination and to find the appropriate increment values to produce optimal anatomical image information.

Methods: This type of research is quantitative with an experimental approach. The study was conducted at the RSUD. Tugurejo Semarang, the image was taken from abdominal MSCT examination in 5 patients with a variation of increments of $100 \%(8 \mathrm{~mm}), 50 \%(4 \mathrm{~mm}), 30 \%(2,4 \mathrm{~mm})$. The results of the study were assessed by 3 respondents. Data analysis used the kappa statistical test, crosstabulation, and friedman.

Results: From the statistical test, the results of the $2.4 \mathrm{~mm}$ increment value show clear anatomical criteria and can detect small nodules. Supported by using friedman statistical test $p$-value $=0.000$ which means that $\mathrm{p}$-value $<0.05$ thus $\mathrm{Ha}$ is accepted so that there are differences in anatomical image information.

Conclusion: The most optimal increment value is $30 \%(2.4 \mathrm{~mm})$ because it has the highest mean rank value of 2.37 .
\end{abstract}

Keywords: Increment Variation; Information of Anatomic; Abdominal MSCT; Nodul Hepar.

\section{Pendahuluan}

Nodul hepar merupakan tumor yang berukuran kurang dari $2 \mathrm{~cm}$ dan bersifat tunggal maupun multipel. Nodul hepar tersering merupakan metastasis karsinoma, dengan colon, paru-paru, dan payudara sebagai tempat karsinoma (Robbins dkk, 2007).

MSCT yang digunakan untuk mendeteksi nodul hepar yaitu MSCT abdomen. Pemeriksaan ini dilakukan dengan pemasukan media kontras untuk menilai kelainan yang terdapat di dalam rongga abdomen dan mendapatkan irisan-irisan tertentu pada tubuh manusia seperti irisan axial, sagital, dan coronal. Irisan axial sangat dibutuhkan dalam pemeriksaan MSCT abdomen karena dengan irisan axial dapat mengetahui lebih jelas lokasi nodul dan memudahkan dalam mengukur diameter nodul (Baron, dkk, 2012). MSCT abdomen yang dilakukan menggunakan tiga fase (fase arteri, fase vena dan fase delay). Pada scanning fase arteri lebih mudah menampakkan nodul yang hipervaskular. Menurut Fishman, Elliot K (2004), bahwa fase arteri dapat mengidentifikasi $15 \%$ sampai $30 \%$ lebih nodul dari pada vase vena. Perbedaan terbesar dalam sensitivitas untuk nodul (kurang dari 2-3 cm) yang mungkin terlewatkan pada saat scanning fase vena. Citra fase vena berguna untuk mendeteksi nodul hepar yang hipovaskular karena parenkim hepar melebar secara maksimal pada fase ini (Bilici, dkk, 2014). Citra fase delay hanya untuk menambahkan lebih lanjut citra fase arteri dan vena saja, hampir $10 \%$ dari nodul terdeteksi pada fase delay. Fase arteri sangat direkomendasikan untuk deteksi nodul dengan optimal.

Reformat gambar pada Multi Planar Reformation (MPR) terdapat suatu proses yaitu rekonstruksi increment. Increment adalah jarak antara gambaran rekonstruksi dalam data volume. Terdapat tiga cara rekonstruksi increment yaitu 
increment overlapping, increment contiguous dan increment gap. Penggunaan increment overlapping diatur lebih kecil dari ukuran slice thickness, untuk increment contiguous harus diatur sama dengan ukuran slice thickness, sedangkan untuk increment gap diatur lebih besar dari ukuran slice thickness. Semakin kecil rekonstruksi increment yang digunakan maka semakin meningkatnya kualitas gambaran dan mendeteksi nodul yang ada (Ji, et. al, 2007). Menurut Seeram (2009), praktik klinik menunjukkan bahwa menggunakan overlapping $50 \%$ terdapat peningkatan deteksi nodul sebesar $10 \%$ daripada menggunakan increment yang berhimpitan. Dijelaskan juga jika menggunakan increment overlapping, 33\% nodul lebih dapat diidentifikasi dengan baik. Sedangkan increment yang tidak berhimpitan, nodul yang kecil tidak dapat dievaluasi dengan baik (Brink, et al, 1994). Tujuan dari penelitian ini yaitu untuk mengetahui perbedaan informasi citra anatomi pada penggunaan variasi increment pemeriksaan MSCT abdomen irisan axial kasus nodul hepar dan untuk mengetahui penggunaan variasi increment yang sesuai sehingga menghasilkan informasi citra anatomi pemeriksaan MSCT abdomen irisan axial kasus nodul hepar yang optimal.

\section{Metode}

Jenis penelitian yang digunakan pada Tugas Akhir ini yaitu jenis penelitian kuantitatif dengan pendekatan eksperimen. Lokasi penelitian yang digunakan penulis di RSUD. Tugurejo Semarang. Subjek penelitian menggunakan 3 orang dokter spesialis radiologi yang sudah berpengalaman kerja di bidang radiologi selama 3 tahun khususnya MSCT. Waktu penelitian dilakukan pada bulan Maret-Mei 2019.

Dalam penelitian ini penulis menggunakan populasi seluruh pemeriksaan MSCT abdomen kasus nodul hepar. Sampel diambil dengan metode insidental yaitu teknik penentuan sampel berdasarkan kebetulan (semua pasien pemeriksaan MSCT abdomen kasus nodul hepar yang kebetulan bertemu dengan peneliti dapat digunakan sebagai sampel). Banyaknya sampel yang digunakan yaitu 5 pasien pemeriksaan MSCT abdomen kasus nodul hepar pada penggunaan variasi increment $8 \mathrm{~mm}, 4$ $\mathrm{mm}$, dan $2,4 \mathrm{~mm}$. Sampel tersebut harus mewakili kriteria inklusi dan eksklusi.

Alat dan bahan penelitian : pesawat MSCT, injector, monitor, informed consent, film, media kontras water soulable $80 \mathrm{cc}, \mathrm{NaCl} 30 \mathrm{cc}$, needle 20, syring, pasien MSCT abdomen kasus nodul hepar, Hasil citra pemeriksaan MSCT abdomen irisan axial kasus nodul hepar.

Evaluasi dilakukan oleh 3 dokter spesialis radiologi sebagai observer dan alat ukur pada penelitian ini menggunakan kuisioner yang digunakan untuk menilai citra MSCT abdomen kasus nodul hepar yang dihasilkan. Penilaian dilakukan terhadap informasi citra anatomi pada hepar. Menilai dari arteri hepatica, vena porta, lobus kanan dan kiri hepar, batas tepi hepar, parenchyma hepar dan nodul oleh dokter spesialis radiologi

Penilaian responden dilakukan dengan cara memberikan check list pada kolom kuisioner sesuai dengan kejelasan informasi citra anatomi (Sugiyono, 2010) yaitu : kolom check list ke-3 berarti "jelas", diberikan apabila organ yang diamati tampak jelas, berbatas tegas dan mudah dilakukan evaluasi. Kolom check list ke-2 berarti "cukup jelas" diberikan apabila organ yang diamati tampak jelas tetapi batas tidak tegas. Kolom check list ke-1 berarti "kurang jelas" diberikan apabila organ yang diamati tidak terlihat jelas serta dokter spesialis radiologi sulit mengevaluasi informasi citra anatomi.

Analisis data dilakukan menggunakan teknik SPSS. Data hasil kuisioner yang diperoleh dari hasil ekspertisi 3 dokter spesialis radiologi masingmasing menganalisis 5 lembar film yang berisi citra radiograf dari masing-masing sampel, dimana di dalam 1 film terdapat 16 slice yang terdiri dari variasi increment $8 \mathrm{~mm}, 4 \mathrm{~mm}$, dan $2,4 \mathrm{~mm}$ pada pemeriksaan MSCT abdomen kasus nodul hepar. Data yang dihasilkan merupakan data ordinal dari hasil jawaban kuisioner yang diberikan kepada dokter spesialis radiologi mengenai kejelasan informasi citra anatomi. Hasil penilaian ketiga dokter spesialis radiologi dilakukan uji kappa untuk mengetahui tingkat objektivitas dari penilaian ketiga responden terhadap informasi citra anatomi dengan penggunaan variasi increment tersebut. Selanjutnya dilakukan uji crosstabulation untuk menganalisis data sehingga mengetahui presentase penilaian kejelasan informasi citra anatomi dari responden. Uji friedman untuk menentukan informasi citra anatomi yang lebih baik dari penggunaan variasi increment $8 \mathrm{~mm}, 4$ $\mathrm{mm}$, dan $2,4 \mathrm{~mm}$ dengan mendeskripsikan dari nilai mean rank. Jika $p$-value lebih kecil atau sama dengan 0,05 maka Ha diterima dan Ho ditolak sehingga ada perbedaan. 


\section{Hasil dan Pembahasan}

Penelitian dilakukan terhadap 5 orang pasien dengan objek abdomen kasus nodul hepar berjenis kelamin pria dan wanita.

Tabel 1. deskripsi pasien berdasarkan jenis kelamin

\begin{tabular}{ccc}
\hline Jenis Kelamin & Jumlah & Presentase \% \\
\hline Pria & 2 orang & $40 \%$ \\
Wanita & 3 orang & $60 \%$ \\
\hline Jumlah & 5 orang & $100 \%$ \\
\hline
\end{tabular}

Berdasarkan tabel diketahui penelitian ini menggunakan 5 orang pasien dengan presentase pria $40 \%$ dan wanita $60 \%$.

Citra MSCT abdomen irisan axial kasus nodul hepar yang diperoleh dari 5 orang pasien sebagai sampel, kemudian dilakukan rekonstruksi variasi increment $8 \mathrm{~mm}, 4 \mathrm{~mm}, 2,4 \mathrm{~mm}$ sebagai berikut :

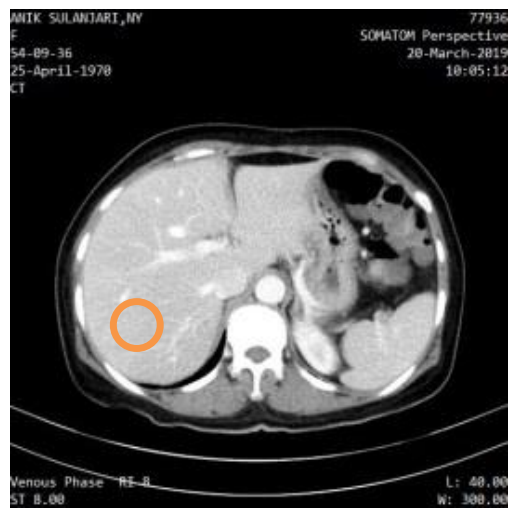

Gambar 1. Citra MSCT irisan axial dengan variasi increment $8 \mathrm{~mm}$

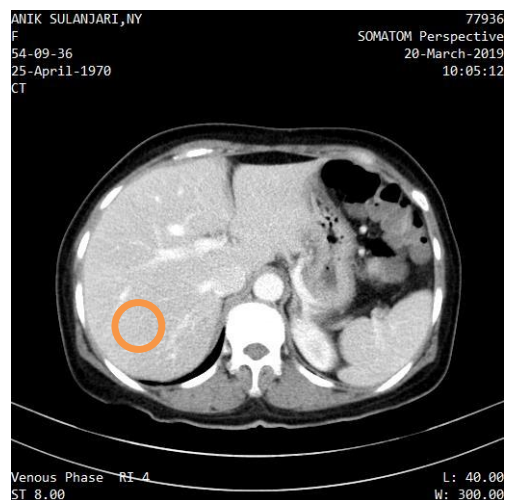

Gambar 2. Citra MSCT irisan axial dengan variasi increment $4 \mathrm{~mm}$

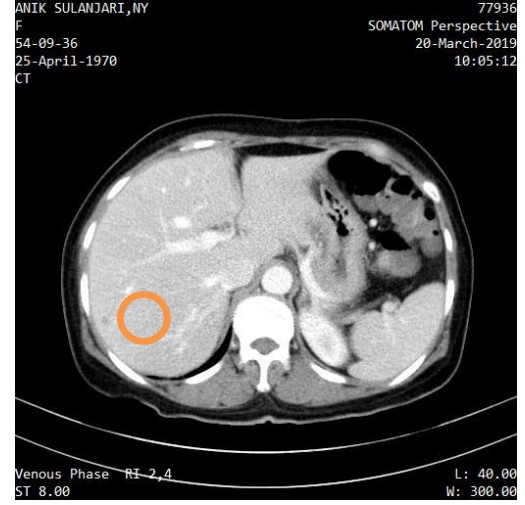

Gambar 3. Citra MSCT irisan axial dengan variasi increment $2,4 \mathrm{~mm}$

Berdasarkan citra yang didapatkan memperlihatkan perbedaan informasi citra anatomi dalam mendeteksi nodul kecil pada hepar. Untuk citra dengan variasi increment $8 \mathrm{~mm}$ nodul kecil pada hepar terlihat kurang jelas dan variasi increment $4 \mathrm{~mm}$ nodul kecil pada hepar terlihat cukup jelas sedangkan citra dengan variasi increment 2,4 $\mathrm{mm}$ nodul kecil pada hepar terlihat jelas.

Hasil dari penilaian responden selanjutnya dilakukan uji kappa untuk mengetahui tingkat objektivitas dari penilaian ketiga responden terhadap informasi citra anatomi dengan penggunaan variasi increment. Adapun hasil uji kappa yaitu sebagai berikut :

Tabel 2. uji kappa responden 2 dan 3

\begin{tabular}{|c|c|c|}
\hline & $\begin{array}{l}\text { Value } \\
\text { kappa }\end{array}$ & Keterangan \\
\hline $\begin{array}{l}\text { Informasi citra anatomi } \\
\text { pada variasi increment }\end{array}$ & 0,749 & Baik \\
\hline
\end{tabular}

Berdasarkan hasil uji kappa menunjukkan bahwa responden 2 dan responden 3 memiliki nilai p-value 0,749. Menurut Altman (1991), nilai koefisien kappa antara 0,61 hingga 0,80 menunjukkan tingkat kesepakatan yang baik.

Selanjutnya dilakukan uji crosstabulation untuk menganalisis data sehingga mengetahui presentase penilaian kejelasan informasi citra anatomi dari responden 2 dan responden 3.

Tabel 3. uji crosstabulation responden 2 dan 3

\begin{tabular}{ccccc}
\hline$\% \mathrm{R}$ & Kurang jelas & Cukup jelas & Jelas & Jumlah \\
\hline$\% \mathrm{R} 2$ & $12,2 \%$ & $26,7 \%$ & $61,1 \%$ & $100 \%$ \\
$\% \mathrm{R} 3$ & $7,8 \%$ & $30,0 \%$ & $62,2 \%$ & $100 \%$ \\
\hline
\end{tabular}


Tabel 4. deskripsi nilai rata-rata hasil penilaian responden dari setiap kriteria anatomi

\begin{tabular}{ccccr}
\hline & Citra Anatomi yang & \multicolumn{3}{c}{ Variasi Increment } \\
\cline { 3 - 5 } No & dinilai & $8 \mathrm{~mm}$ & $4 \mathrm{~mm}$ & $2,4 \mathrm{~m}$ \\
\hline 1 & Arteri hepatica & 10 & 12 & 13 \\
2 & Vena porta & 11 & 13 & 14 \\
3 & Lobus kanan dan kiri & 11 & 13 & 14 \\
4 & Batas tepi hepar & 11 & 13 & 14 \\
5 & Parenchyma hepar & 10 & 12 & 15 \\
6 & Nodul & 10 & 12 & 14 \\
\hline & Jumlah nilai rata-rata & 63 & 75 & 84
\end{tabular}

Untuk mengetahui perbedaan informasi citra anatomi pada keseluruhan pasien dilakukan dengan uji friedman. Pengujian ini bertujuan untuk mengetahui bermakna atau tidak dari perbedaan informasi citra anatomi pada penggunaan variasi increment pemeriksaan MSCT abdomen irisan axial kasus nodul hepar. Perbedaan tersebut dapat dilihat pada tabel berikut :

Tabel 5. Uji friedman keseluruhan variasi

\begin{tabular}{ccc}
\hline $\mathrm{N}$ & Chi-Square & Asymp Sig. \\
\hline 30 & 20,462 & 0,000 \\
\hline
\end{tabular}

Berdasarkan hasil uji friedman dapat dilihat bahwa data masing-masing increment sejumlah 30 data atau sampel. Untuk tabel uji friedman dapat dilihat nilai signifikansi $p$-value sebesar 0,000 yang berarti $p$-value $<0,05$ sehingga terdapat perbedaan informasi citra anatomi pada masing-masing variasi increment.

Untuk melihat hasil informasi citra anatomi yang optimal pada pemeriksaan MSCT abdomen irisan axial kasus nodul hepar dengan variasi increment digunakan nilai mean rank pada hasil uji friedman. Nilai tersebut dapat dilihat pada tabel berikut :

Tabel 6. Uji mean rank variasi increment

\begin{tabular}{ccc}
\hline No & Variasi Increment & Nilai Mean Rank \\
\hline 1 & $8 \mathrm{~mm}$ & 1,60 \\
2 & $4 \mathrm{~mm}$ & 2,03 \\
3 & $2,4 \mathrm{~mm}$ & 2,37 \\
\hline
\end{tabular}

Berdasarkan tabel diatas didapatkan nilai mean rank dari keseluruhan variasi increment yaitu increment $8 \mathrm{~mm}$ sebesar 1,60, increment $4 \mathrm{~mm}$ sebesar 2,03 dan nilai mean rank dari increment 2,4 mm sebesar 2,37, sehingga dapat dilihat nilai mean rank tertinggi terdapat pada variasi increment 2,4 $\mathrm{mm}$.

Berdasarkan data skor secara keseluruhan pada penilaian informasi citra anatomi pemeriksaan MSCT abdomen irisan axial kasus nodul hepar yang diperoleh dari hasil kuisioner responden menunjukkan adanya perbedaan informasi citra anatomi pada penggunaan variasi increment pemeriksaan MSCT abdomen irisan axial kasus mmodul hepar. Setiap variasi increment memiliki 3 kemampuan yang berbeda dalam memperlihatkan 14 informasi citra anatomi yang ada pada hepar 14 meliputi arteri hepatica, vena porta, lobus kanan ${ }_{4}$ dan kiri, batas tepi hepar, parenchyma hepar, nodul. ${ }_{5}$ Pada nilai increment $8 \mathrm{~mm}$ yang berhimpit memperlihatkan kriteria citra anatomi arteri hepatica, vena porta, parenchyma hepar cukup jelas, lobus kanan dan kiri, batas tepi hepar tampak jelas berbatas tegas tetapi nodul tampak kurang jelas sehingga kurang sesuai untuk mendeteksi nodul kecil pada hepar.

Untuk nilai increment $4 \mathrm{~mm}$ mampu memperlihatkan kriteria citra anatomi arteri hepatica, vena porta, lobus kanan dan kiri, parenchyma hepar dengan jelas dan batas tepi hepar tampak jelas berbatas tegas, nodul kecil yang ada pada hepar tampak cukup jelas dibandingkan dengan penggunaan nilai increment $8 \mathrm{~mm}$.

Sedangkan nilai increment $2,4 \mathrm{~mm}$ mampu memperlihatkan kriteria citra anatomi arteri hepatica, vena porta, lobus kanan dan kiri, batas tepi hepar, parenchyma hepar, dan nodul dengan jelas dan berbatas tegas karena penggunaan nilai increment $2,4 \mathrm{~mm}$ data volume yang didapat sangat banyak sehingga lebih jelas dalam mengevaluasi nodul kecil yang ada pada hepar.

Hal ini dapat dilihat dari nilai rata-rata yang didapatkan pada masing-masing penilaian responden mengenai penggunaan variasi increment terhadap informasi citra anatomi yaitu nilai increment $8 \mathrm{~mm}$ memiliki nilai rata-rata 63 , nilai increment $4 \mathrm{~mm}$ memiliki nilai rata-rata 75 , dan nilai increment $2,4 \mathrm{~mm}$ memiliki nilai rata-rata 84 . Hasil dari nilai rata-rata kemudian dibuktikan dengan dilakukan uji beda friedman untuk menunjukkan nilai signifikansi $p$-value yaitu sebesar 0,000 atau $(p$-value $<0,05)$ yang berarti Ho ditolak dan Ha diterima, dengan demikian dapat diartikan bahwa terdapat perbedaan informasi citra anatomi pada penggunaan variasi increment pemeriksaan MSCT abdomen irisan axial kasus nodul hepar. Dari hasil mean rank yang didapatkan pada keseluruhan variasi increment yaitu nilai increment $8 \mathrm{~mm}$ sebesar 1,60 ,nilai increment 4 $\mathrm{mm}$ sebesar 2,03 dan nilai increment $2,4 \mathrm{~mm}$ sebesar 2,37, sehingga didapatkan nilai mean rank tertinggi pada nilai increment 2,4 $\mathrm{mm}$. Menurut Brink, et al (1994), rekonstruksi increment yang semakin kecil dari slice thickness akan meningkatkan kualitas citra yang baik dan memberikan detail struktur anatomi yang tinggi 
khususnya pada citra rekonstruksi MPR, tetapi dengan konsekuensi meningkatkan waktu untuk processing citra, kebutuhan penyimpanan dan waktu membaca untuk dokter spesialis radiologi. Menurut peneliti, hasil dari pengujian di lapangan dan yang ada di teori sudah ada kesamaan yaitu dengan rekonstruksi increment 2,4 $\mathrm{mm}$ jumlah data yang dihasilkan lebih banyak sehingga meningkatkan detail citra anatomi hepar, karena semakin rapat irisannya maka kemungkinan besar objek yang tidak terkena scan akan berkurang sehingga jika terdapat kelainan seperti nodul kecil yang ada pada hepar dapat diidentifikasi dengan baik dan dokter spesialis radiologi tidak kehilangan informasi dalam membaca hasil dari MSCT abdomen irisan axial kasus nodul hepar tersebut karena hasil informasi citra yang dihasilkan optimal.

\section{Simpulan}

Ada perbedaan informasi citra anatomi pada penggunaan variasi increment MSCT abdomen irisan axial kasus nodul hepar dibuktikan dengan nilai rata-rata dari penilaian responden yang menunjukkan bahwa variasi increment $2,4 \mathrm{~mm}$ mendapatkan nilai rata-rata tertinggi sebesar 85 . Diperkuat dengan menggunakan uji statistik friedman test, dihasilkan nilai signifikansi $p$-value sebesar 0,000 yang artinya $p$-value $<0,05$ dengan demikian Ha diterima.

Nilai variasi increment untuk mendapatkan hasil informasi citra anatomi yang optimal pada pemeriksaan MSCT abdomen irisan axial kasus nodul hepar yaitu rekonstruksi increment overlapping $30 \%(2,4 \mathrm{~mm})$ dari slice thickness 8 $\mathrm{mm}$ memiliki nilai mean rank sebesar 2,37. Semakin kecil nilai rekonstruksi increment maka kualitas citra meningkat, hasil citra yang didapat semakin banyak, sehingga dokter spesialis radiologi mendapatkan informasi citra yang optimal. Nodul kecil yang ada pada hepar dapat diidentifikasi dengan baik dan tidak ada informasi citra yang hilang.

\section{Daftar Pustaka}

Ahirwar Chandra Prakash, Patil Abhijit, Soni Neelam. 2016. Role of Triple Phase Computed Tomography Findings for Evaluation of Hepatic Lesions. International Journal of Research in Medical Sciences.

Altman. 1991. Practical Statistic for Medical Students. London : Chapman and Hall.
Andeen Nicole K, Bhargava Puneet, Dighe Manjiri K, Shriki jabi E. 2015. CT of Atypical and Uncommon Presentations of Hepatocellular Carcinoma. AJR.

Ardiyanto Jeffri, Darmini, Sari Widya Purnama. 2016. Analisis Variasi Rekonstruksi Increment Overlapping Terhadap Informasi Citra Anatomi Pada Pemeriksaan MSCT Nasofaring dengan Klinis Karsinoma. Health Polytechnics of Semarang-Indonesia.

Ardiyanto Jeffri, Fatimah, Rustanto, Saputro Sudibyo Dwi, Setiyawan Dwi Adi, Sugeng Dwi, Wijokongko Sigit. 2017. Protokol Radiologi CT Scan dan MRI. Inti Medika Pustaka, Magelang.

Ballinger. 2012. Merrils Atlas of Radiographic Positions and Radiologic Procedures. Volume Three. Tenth Edition. St, Louis Misbourt : Mosby Inc.

Baron Richard, Bartolozzi Carlo, Zech Christoph Johannes. 2012. Multislice-CT of the Abdomen. Springer, New York.

Bilici Aslan, Cetin Bulent. 2014. Temuan Karsinoma Hepatoseluler Melalui Tomografi Komputerisasi Multidetektor Dinamis Pada Pasien Positif dan Negatif Virus Hepatitis- $B$.

Bontrager Kenneth L, Lampignano John P. 2014. Text Book of Radiographic Positioning and Related Anatomy. Fifth Edition, Mosby Inc : Toronto.

Brink James A, Heiken Jay P, Schlueter Francis J, Vannier Michael W. 1994. Helical CT : Principles and Technical Considerations.

Bushberg, JT. 2003. The Essensial Physic of Medical Imaging. Second Edition. Philadelphia, USA.

Corwin, Elizabeth J. 2009. Buku Saku Patofisiologi. EGC, Jakarta.

Fishman, Elliot K. 2004. Multidetector CT : Principles, Techniques, \& Clinical Application.

Galansky Michael, Prokop Mathias. 2003. Spiral and Multislice Computed Tomography of the Body. Thieme, Germany.

Moeller, Torsten B. 2007. Normal Findings in CT and MRI. New York.

Notoatmojo, Soekidjo. 2010. Metodologi Penelitian Kesehatan. Rineka Cipta, Jakarta.

Pearce, Evelyn. 2015. Anatomi dan Fisiologi Untuk Paramedis. PT Gramedia Pustaka Utama, Jakarta.

Seeram, E. 2009. Computed Tomography : Physical Principles, Clinical Applications and Quality Control. Fourth Edition, Philadelphia, WB Saunders Company.

Siemens. 2003. Computed Tomography : Its History and Technologist. Siemens Medical Solution, Muechen, Germany.

Sobotta. 2013. Atlas Anatomi Manusia. Edisi 23. EGC, Jakarta.

Sugiyono. 2010. Metode Penelitian Kuantitatif Kualitatif dan R\&D. Alfabeta, Bandung.

Sulistyowati Dwi, Witjaksono Budi Prijo. 2017. Analisis Variasi Overlap Data Terhadap Citra Anatomi Axial CT-Scan Thorax Pada Kasus Tumor Paru. Health Polytechnics of Semarang-Indonesia. 
Underwood J. C. E. 2000. Patologi Umum dan Sistematik. Vol. 2. EGC, Jakarta. 